\title{
Divine Presence, then the covenants. An essay on narrative and theological precedence (Part three)
}

NGTT DEEL 55, NR 3 \& 4, 2014

Leder, Arie C

University of the Free State

\section{KEYWORDS}

Narrative systematic theology, Theological topics, Diaspora, Exile,

Divine presence

\section{TREFWOORDE}

Narratiewe sistematiese teologie, Teologiese onderwerpe, Diaspora, Ballingskap,

Goddelike teenwoordigheid

\section{CONTACT DETAILS}

Arie C Leder

Research Associate, Faculty of Theology, University of the Free State

Professor of Old Testament, Calvin Theological Seminary

3233 Burton SE, Grand Rapids, Michigan, USA

lede@calvinseminary.edu 


\section{INTRODUCTION}

Part one of this essay argued that the topic of divine presence, not covenant, is fundamental for the divine human relationship - as depicted in the theological prologue (Gen 1:1-2:3) and developed in the rest of Genesis-Kings (GK) - within the framework of exile from the divine presence in the Garden (Gen 3) to exile from the divine presence in Jerusalem (2 Kgs 23:27; 24:3,20). Part two argued that the depicted covenant making events in their narrative locations are the means by which the suzerain swears a covenant oath to secure Noah, his family, and all living things (Gen 6,9) and, subsequently, Abraham and David's promised future (Gen 15; 2 Sam 7), to restful life in the divine presence. Covenants are also the means by which Abraham and Israel swear an oath of loyalty in the Lord's presence as they walk the Lord's way among the nations (Gen 17; Ex 19 - 24). Nowhere is the Lord depicted as failing to comply with his pledged promises. God's people, however, regularly fail to comply with their sworn loyalty at Sinai in the desert and the land. For this they are exiled from the divine presence in Jerusalem, as were Adam and Eve from the divine presence in the Garden. In the context of this exile the covenant with David depicts hope: the Lord pledged to establish David's house to secure his temple presence, a pledge evoked with the exiled Jehoiachin's elevation to the king's table (2 Kgs 25:27-30). ${ }^{1}$

In the third and last part of this essay I will reflect on the consequences of the precedence of the topic of divine presence over that of covenant in GK. I will first argue that GK has structured theological interests in its own right, which must be accounted for in any wider canonical reading and any contemporary systematic theological constructs derived from it. GK's own theological structure develops its theology of covenant in the context of the theological problem GK enunciates in its opening chapters: exile from the divine presence.

\section{GK'S NARRATIVE THEOLOGICAL ORGANIZATION}

The reading of GK in parts one and two of this essay is shaped by an understanding that this text is not in some sense pre-theological, but fully theological in its own right. $^{2}$ That is, it re-presents the relationship between God and the nations, and

1 See von Rad (1984c:219-221) and Leder (2013:216-18). GK does not anticipate the new covenant of Jeremiah and Ezekiel. The new covenant depicted in Luke (22:28) and Hebrews (9:24) secure the future of God's people in the divine presence. Jesus Christ accomplishes this as the son of David.

2 Against, for example, Vos (1980a:5), who argues that exegetical theology focuses on "the appropriation of that supernatural process by which God has made Himself the object 
thereafter between God and Israel, by depicting the past actions of God, the nations, and Israel from the point of view of humanity's exile from the divine presence for defiling God's Garden presence. The rest of the narrative is an exposition, in ancient historiographical form, of the problem of humanity's restless wandering outside this Garden presence (Gen 4:12). This exposition depicts a temporal solution of that problem at Sinai for Abraham and Sarah's descendants, the subsequent complications at Sinai and in the desert, the divine indwelling of the Jerusalem temple, and an exile of Israel from that temple for its defilement of the place of the divine presence.

The theology of divine presence shapes the entire narrative, beginning with Genesis $1: 1-2: 3$, by stating the fundamental truth of all reality coram Deo, and depicting the narrative problem in Genesis 2:15-17 and 3:1-22. This narrative problem is fully developed with the humanity's expulsion by God in Genesis 3:23-24. That is, although humanity failed to comply with divine instruction and thus defiled the earthly dwelling-place of the divine, it is the subsequent action of God that defines the problem GK develops in the narrative on several levels. First, the text depicts God as the exiler of humanity from that place to which they cannot return by virtue of the cherubim's guarding the entrance. Second, by exiling humanity from that place without which there is no life, God has condemned humanity to a life in which the power of death to defile is now the normal human experience. ${ }^{3}$ Third, although GK recognizes the theological problem of a transgression which defiles the Garden presence, its concern is not primarily to show the way to forgiveness for that disobedience, but to show the way God designed to bring his human creatures back from a living death into that presence from which he himself had barred them (drk, Gen 3:24). GK's theological problem then is a God-problem: the deity who has

of our knowledge," which suggests a recovery of something behind the text. Elsewhere: "the Word of God furnishes the material for Theology in this scientific sense, but is no Theology ... it could only spring up after revelation and the formation of the Scriptures had been completed. ... even that which the Apostles teach is in no sense primarily to be viewed under the aspect of Theology" (1980a:21). Emphasis original. Similarly, Fee and Stuart (1993:82): who argue that OT narratives "do not necessarily teach directly, they often illustrate what is taught directly and categorically elsewhere". Emphasis original.

3 Expulsion from the presence of God in territorial terms, whether Garden, desert camp, or land, delivers one to the place where disorder and chaos reign, over against that place where God's orderliness structures life. Being in that unclean place anticipates the total uncleanness of death that separates one from the land of the living. Whenever the realm of death intrudes, even in the desert camp or land (skin eruptions, touching a corpse, etc.; cf. Lev $11-15)$, the appropriate cleansing rites are required. For a brief discussion see Gorman (1997:14-16). 
consigned humanity to death is also the deity who brings defiled humanity back into his dangerous presence (Ex 20:18-20; 24:17; cf. Heb 12:28-29). As GK unfolds it presents a "systematic" exposition of the God-problem defined in its opening chapters.

\subsection{GK as a theological document}

Research on the nature of ancient historiography suggests it is a sophisticated literary re-presentation of the past, shaped by its selection and organization of past events and which in that shape makes claims upon its intended audience. Thus, GK is not a chronology of everything that actually happened, but a selectively shaped re-presentation of the past relationship between God and his people. ${ }^{4}$ Like theological-royal propaganda elsewhere in the ancient world, GK argues in favour of a particular deity and his territorial interests. This more recent discussion of the nature of OT historiography was preceded by nineteenth and twentieth century critical methods of exegesis that suggested in their own way that OT historiography were tendentious, if not theological. Wellhausen, for example, argued that Isaiah's ethical monotheism was the high point of ancient Israel's religion and that its nadir was expressed in material he attributed to post-exilic Judaizing interests. Although Israel's religion is not considered to be the same as its theology, ${ }^{5}$ others have argued that the underlying historical literature demonstrates recognizably coherent theological points of view associated with the Yahwist, Priestly, or Deuteronomist traditions. ${ }^{6}$ The interweaving of these traditions, however, was not considered to have produced a coherent theological whole; the received shape of the text was a sum of parts less than the whole. Nevertheless, the underlying material was in some sense considered theological. Scholarship on the Deuteronomic History and the Hexateuch reflects similar conclusions. Although Noth's thesis was resolutely historical, subsequent scholarship on the double and triple editions recognize the tendentious, even theological, character of the Deuteronomist (whether Dtr1, Dtr2, DtrG, DtrN or DtrP). Von Rad's form-critical study of the development of the credo of Deuteronomy 26:5-9 treats Israel's historical self-understanding from the point of view of Geschichte not Historie. Most recently, enneateuchal studies argue for

4 It is not fiction, Long (1999). For an extended review of the philosophy of history and how that has shaped historiography in the $19^{\text {th }}$ century, see White (1973); on narrative representation of reality, see White (1987); on the beginning of ancient historical narrative and throne-room reliefs, see Winter (1985). The latter's research is applied to Exodus in Leder (1992).

5 See Leder (2012).

6 Brueggemann and Wolff (1975); Von Rad (1984c). 
a "Theology of the Deuteronomistic Composition of the History of the People of Israel from Exodus to Exile." That GK is theological, therefore, is not so much an issue; how it is theological is. That takes us to the adjective "systematic."

\subsection{GK as a systematic theological document}

In this essay I use the term "systematic" to describe the peculiar organization of the whole of GK as an historiographic literary whole, greater than the sum of its various antecedent historico-theological literary threads that are now subsumed to the tapestry of its canonical shape. I will illustrate this textual weaving with two examples, one in terms of the Priestly material in the Pentateuch and a second in terms of the theological topics of creation and redemption.

Whatever else one might say about the texts scholars have identified as priestly, it is difficult to ignore these texts' interest in order, dates, liturgical instructions and temple which Genesis 1:1-2:4a, Exodus 24-40, Leviticus, and Numbers have in common. Attributing Genesis 1:1-2:4a to priestly and 2:4b-25 to Yahwistic interests has led to suggestions that they represent two accounts of creation, a conclusion possible on the basis of a method interested in reconstructing the underlying pentateuchal material. But in the tapestry that is Genesis 1:1-2:25 these narrative threads have been woven into a new textual tapestry organized by the toledoth (Leder 2012), such that the so-called second creation narrative is intentionally separated from Genesis 1:1-2:3 by a toledoth formula with a view to telling what happened with and in the creation in general and specifically with respect to the planting of a garden, and the creation and vocation of humanity. This is then joined to the narrative of what happened in that place to those people and their descendants. Genesis 2:4 - 4:26 now forms part of the new tapestry of we know as Genesis. ${ }^{8}$ And, when the narrative development takes the reader to Exodus 39 - 40 and the reader recognizes phrases from Genesis 1:1-2:3 (Weinfeld 1981), the tapestry depiction concludes the GenesisExodus account with the narrative word-thread with which it began: Genesis begins with a creation-temple and Exodus ends with a particular post-lapsarian instantiation thereof. Add to this the complex historical and artistic organization of the narrative in between this priestly beginning and ending of Genesis-Exodus, and we have a carefully developed exposition of the theological problem defined in the opening chapters of Genesis, that exhibits its own systematic organization.

7 Gertz, Berlejung, Schmid, Witte (2012:376-379); for the theology of Genesis-Kings (2012:269).

8 Wesselius (2005:45) describes such textual discontinuities as enjoying a "supercontinuity of highly similar stories, episodes and type-scenes." 
Accordingly, recognizing the presence and placement of priestly material in the received text lends a certain colour to the textual tapestry, now a synchronic whole. The synchronic systematics of a GK that begins with a description of creation as a temple, combined with subsequent material on the tabernacle and the instructions from the Tent of Meeting (Lev 1:1) may not be the biblical-theological systematics one looks for today, but then GK's re-presentation of the past does not have to meet contemporary standards.

Von Rad's exposition of the "problem" of the theological topic of creation argued that because creation theology was developed later than the theology of history or redemption, it ought to be subordinated to the theology of history or redemption (Von Rad, 1984). That is, the chronological development of these theological topics, as reconstructed by a scholarship methodologically committed to understanding the text in terms of the history of its composition, should determine the systematic relationship between these two doctrines. The consequent effect on the reading of the received text is that the theology of the Pentateuch does not begin with the creation narrative of Genesis, but with the call of Abraham, for Genesis 1 - 11 was added to the patriarchal stories later (Von Rad, 1983:63-67). Rolf Knierim, however, argues that this ignores the systematic relationship these theological topics enjoy in the received text. He writes that it is better to accept that "in the Pentateuch creation is regarded as the beginning of history, and hence as part of our overall horizon identified as history. In this argument, our sources are said to have a systematic perspective, regardless of the fact that Israel's theology of history is older than its theology of creation" (1995:180). The material selected for GK, topical in its own way and originating in different times and contexts, has been creatively woven into a narrative entirely different from any of its constituent elements, and as such has its own theological interests. Rendtorff's Old Testament theology echoes Knierim's argument for a systematic shape of the biblical text in that he discerns ten theological "topics" as they emerge in "their order of appearance in the 'retelling' of the biblical books" (2005:1-3): Creation; covenant and election; the fathers of Israel; the promises and entrusted land; the first and second exodus; the centre of Israel's life: torah; the cult; Moses; the kingship of David; and Zion. The discussion of the topics is carried on through the various literatures as they evoke the topic, without, however, providing a complete systematics of each theological topic (2005:1-3, 416, and $717-721) .{ }^{9}$

9 Rendtorff's canonical "retelling" raises the question of the role of the canonical form, MT or LXX, in determining the textual units under consideration. The search for the historical shape of the canon's underlying literary elements has crossed MT's boundaries because it was impossible to move compositionally, for example, from 2 
In terms of the relationship between the interweaving of the topics of divine presence and covenant in GK, there is no doubt that the topic of divine presence emerges first and that of covenant subsequently, not only in terms of the narrative development but especially in terms of the theological problem GK formulates in its opening chapters: the Noahic covenant addresses the problems of a humanity exiled from the divine presence. Understanding GK as a larger textual unit with its own theological intentions and shape we move on to what that means for the precedence of divine presence over covenant. I begin with the theological problem GK seeks to solve.

\section{THE THEOLOGICAL PROBLEM OF GK}

Federal theology's deep interest in the depiction of the human failure to comply with divine instruction is based on the analogy of Adam and Christ; Christ is the solution to the problem Adam introduced. As argued by Paul the former solved the latter's problem of intentional disobedience. This Adam-Christ relationship is paired with the Abraham-Christ relationship as well (Gal 3:29), the latter being a further, gracious solution to the problem of human disobedience. Thus the covenant of works is understood to address the universal human problem and the covenant of grace a particularly applied solution to that problem, especially as restated at Sinai. Federal theology reads GK from the point of view of the Pauline AdamChrist analogy. From the point of view of GK, however, Adam plays a minor role; Abraham is the character with and through whom God begins to solve the problem of exile from the Garden presence when divine instruction excises him from the scatteredness of Babel to direct him to "the land," the place where God would dwell in the midst of Abraham's descendants. From Genesis 11:27 on, GK's major interest is in the descendants of the patriarchs, who received the promises, not, however, without maintaining interest in the descendants of Adam and Eve (Gen 12:3; cf. Josh 2; 2 Kgs 5). The particularity of this solution does become universal, but not in GK, and then only by the nations' coming to the Jerusalem-temple (Is 2:1-5; Mic

Kings to Isaiah. Rendtorff, recognizing the compositional character of the text, crosses these canonical-historical boundaries in his retelling of the texts' theological intention. See on the first and second exodus (2005:478-508). Rendtorff does not argue for a theology of the Hexateuch, the Deuteronomistic History, or the Enneateuch, but pulls the topics through beyond those literary-historically determined boundaries. This has the benefit of, for example, moving from the topics of covenant in Genesis, Exodus, 2 Samuel 7, and Zion, through to Isaiah, Jeremiah and Psalms and Chronicles (2005:444$446 ; 575-585)$. For a brief discussion of order of the canon, the grammar of the "law and the prophets", the relationship of historical-critical work to the MT order, the various Greek orders, and a brief discussion of Rendtorff's OT theology, see Seitz (2009:49-76; 60-61, 67-70). 
4:1-5); not their own "Babel" projects. Ultimately, it is through the covenants with Abraham that all who are Christ's, Jew and Gentile, are brought into God's presence, by being incorporated ( $\mathrm{Gal} 3: 14,29$ ) into the body of Christ, which is the temple of the Holy Spirit (1 Cor 3:16).

The Adam-Christ analogy's move from death to life is not only to be understood as a legal act of imputation through union with Christ, however, but also as a cleansing of the unclean: death being the ultimate uncleanness (Gorman 1997:1416). Only the cleansed enter the heavenly temple ( $\operatorname{Rev} 21: 27 ; 22: 15)$. According to GK priestly humanity was created clean and normal; its failure to comply with divine instruction defiles the Garden presence resulting in the defilers' exile from that presence. Consequently humanity is condemned to a restless wandering dying, the extreme unclean conditions. This constant death is resolved by removing death's defilement (cf. Jairus' daughter and the woman with the flow of blood, Mark 5:21-43. Humanity's problem is not only an intentional transgression of a divine stipulation, it is an intentional transgression-defilement in and of a place consecrated by the divine presence, evocative of those sins for which the Day of Atonement was instituted (Lev 16:16). Simply put, in its opening chapters GK depicts the theological problem in terms of a guilty-and-defiled humanity cursed to painful toil east of Eden, far from the presence of God. Cain's restless wandering (Gen 4:12b) exemplifies this inescapable human condition, from which God calls Abraham. The rest of the narrative depicts what God does to bring that humanity back into his life-giving and death-reversing presence, through Abraham's descendants at Sinai and later the Jerusalem temple.

GK only depicts a partially solved theological problem, for those brought into the divine presence who swore covenant loyalty in that presence, still cannot pass by the cherubim (Gen 3:24; Ex 26:1, 31) into the very presence of God. Even worse, GK's last chapters cite Manasseh's defilement of the temple (2 Kgs 23:26) and the consequent deportation of Judah to the place inhabited by the unclean descendants of Adam and Eve: the desert of the nations (Ezek 20:21, 35). GK begins with the universal human problem of exile from God's presence, and ends with a restatement of that problem with respect to a particular human community: Abraham and Sarah's descendants find themselves in exiled to the place from which God had called Abraham: Ur of the Chaldeans (2 Kgs 25:25).

There can be only one reason why GK emphasizes exile from the divine presence at the beginning and ending of its theological depiction of the fundamental problem: to teach Abraham and Sarah's descendants in the diaspora to return to its covenant Overlord in order to live a life of compliance with divine instruction (šwb, and trt $m s ̌ h, 2$ Kings 23:25). Prophets would tell the returned exiles they are a people of 
unclean lips, worthy of the judgment as it awaits a new temple and a new High Priest (Hag 2:1-9; Zech 3). Hebrews addresses the NT people's need for a priest who has given them rest in the very presence of God, but that they are to await a greater rest (Heb 4:9; 9:12; 10:20). From GK and the exilic prophets through Peter and James, Scripture addresses God's people as an exilic and diasporic community whose identity rests in being priestly (1 Pet 2:4-12) and the temple of the Holy Spirit (1 Cor 3:16; 6:19). And, it is the Spirit who enables life in the diaspora (Jn 15; cf. Ezek 37). As argued in parts one and two of this essay, the covenants of Genesis 6 - 9, 15 and 2 Samuel 7 depict God's commitment to solve the problem of a defiled existence outside of God's presence. Unlike the ending of GK, however, the ending of Scripture depicts the cleansed from all humanity entering the New Jerusalem, and the unclean from all humanity remaining in deadly exile ( $\operatorname{Rev} 21: 25-27 ; 22: 14-15)$.

\section{SUMMARY AND FURTHER REFLECTIONS}

Because space does not permit a fuller working out of this reading of GK, I will summarize and suggest further consequences of GK's narrative structure and the topical-theological precedence of divine presence over covenant in the form of propositional paragraphs.

1. GK depicts the canonical community's normative history and as such describes its identity as a defiled, exiled priestly community in two parts. Genesis through Deuteronomy defines the theological problem and its solution at Sinai. At the edge of the land of promise God dwells in the midst of an Israel fully instructed for life in his presence (trt mšh). Abraham and Sarah's descendants' restless wandering among the nations concludes in the Promised Land (Josh 21:44). Joshua through Kings depicts the community's response to instruction in the (landed) presence of God, beginning with sworn commitments to comply (Josh 22-24), but ending with exile from that presence for failure to comply. Negatively stated, GK rebukes and judges Israel for failing to live out its priestly identity received and covenanted at Sinai and reiterated in the Jerusalem temple. Positively, it instructs a people exiled among the nations how to wait for God's renewed indwelling, one secured by God's oath-bound commitments to Abraham (Gen 15) and David (2 Sam 7). Read from this perspective, and beginning with Isaiah 1 , the subsequent prophets form an extended multi-voiced proclamation of rebuke and hope with respect to the problems leading up to and subsequent to the destruction of the Jerusalem temple.

2. From the point of view of method, post-Gabler biblical theology of GK, understood diachronically or synchronically, is interested in the narrative 
location of theological themes, not in terms of previously formulated theological commonplaces. Post-Gabler systematic theology, no matter its preGabler roots, must take account of that development. Thus, covenants in GK should be understood as they are depicted in the narrative flow and context and not within predetermined theological or historical categories.

3. Biblical theological topics in GK emerge in terms of the narrative development of the theological problem, not as a conclusion from the examination and comparison of a variety of texts. Its theology of covenant does not begin with a summary ${ }^{10}$ of features typical of a covenant and drawn from any and all biblical texts without regard to the text's narrative shape, but seeks to re-present the systematic presentation of the theologoumenon as developed in the textual tapestry. Thus the argument that Genesis 2:15-17 depicts a covenant because of the presence of certain features that are typical of a covenants in the Bible sets a particular kind of systematization of scriptural data by collation over against the systematic organization of the narrative. A so-called covenant of works is not required to sustain the Adam-Christ analogy because that analogy only requires corporate re-presentation, ${ }^{11}$ not a particular historical form of that phenomenon. The Garden instruction to which compliance is expected must be read against the creation account where things that come into being are compliant by nature, not by keeping a covenant.

4. Although God is depicted as relating to the nations and his people by covenants, GK does so subsequent to stating the theological problem: the transgression-defilement and subsequent exile of humanity from the divine presence. As depicted, the first covenant is God's response to the ultimate consequence of uncleanness, exile-unto-death and the watery cleansing of the sanctuary-like creation. The response secures humanity in a divinely designed rescue vehicle impervious to death's uncleanness. When pledged, the covenant with Noah secures created reality from similar destructive uncleanness until all those cleansed from the nations enter into an incorruptible space on a new earth where there is no more water ( $\operatorname{Rev} 21: 1,25-27 ; 22: 14-15)$. This suggests that covenant theology should also be construed in priestly terms, in which defilement merits prophetic rebuke according to the Sinai instructions that structure the life of God's special people. This is especially true of the

10 This does not violate the rule of faith, which, according to Bokedal, focused on "the prime doctrines of Scripture, rather than the biblical books as such" (2013:250).

11 Oosterhoff (1972:69-87) works with corporative personality and discusses the different way realism and federalism understands the Adam-Christ analogy. 
prophecies of the priest-prophet Ezekiel who, evoking Jeremiah's words about a new heart in a new covenant, depicts the new covenant in priestly terms of cleansing and the land in terms of Eden (Ezek. 36) and a new temple (Ezek 40 - 48; Jn 2:20; 1 Cor 3:16; Rev 21-22). A covenant theology must include the divine address to the human defilement of the earthly place of God's presence.

5. Covenant first emerges in God's address of the violence that permeates humanity's restless wandering, a covenant in which the God who exiled humanity for transgression-defilement and decided to destroy it (Gen 6:5-8), nevertheless commits himself to secure the future of humanity "in Noah." This universal covenant pledge is particularized "in Abraham," then "in David," and finally, universalized again "in Christ." The crucial covenants are all of the royal grant type, i.e., dependent upon the Deity/Suzerain, not on the vassal. Covenant theology points primarily to God's binding himself to secure a future for humanity than to humanity's binding itself to God.

6. Like ancient imperial covenants, GK depicts its covenants as instruments that manage the problems between a suzerain and his vassals by stipulating the cult and conduct of the people. GK's covenants are of two kinds: those in which God commits himself to the vassal (Gen 6 - 9; 15; 2 Sam 7) in terms of a depicted problem; and those in which the vassals commit themselves to God (Gen 17; Ex $19-24$ ), also in terms of a depicted problem. ${ }^{12}$ Crucial to GK's theology of covenants is that this topic begins with God's irrevocable commitment "to the continuing existence of the world and of humanity." ${ }^{3}$ A similar irrevocable covenant (Gen 15) legally binds God to the promised relationships with Abraham and his descendants (Gen 12:1-3). The failure of vassal loyalty to the covenant of Genesis 17 , massively expressed in failure of Israel and its kings to comply with the Sinai covenant stipulations, occasions the divine pledge to David. Theologically, covenants are redemptive instruments by which God manages human life in exile from his presence until

12 From a biblical theological point of view it is important to note that the Sinai covenant responds to the threat of Pharaoh, Leder (2013:214-216), and not a particular restatement of the covenant of works. The correspondence between Gen 2:15-17 and the Sinai instructions is best understood in terms of the instructions of Leviticus coming from the earthly place of God's indwelling.

13 Rendtorff (2005:433). In terms of our present understanding of the nature of covenants the covenant of works is closest to a treaty in which the focus is on the vassal's commitment, like that of the Sinai covenant, and unlike the Noah covenant, often taken as a universal restatement of the covenant of works. If this is so, the theological problem of GK is more anthropocentric than theocentric. 
that problem is solved (Rev 21:3-4). Until then, God's priestly people are bound to God (Ex 19-24; Gen 17), within the framework of a divine commitment to Abraham and his descendants (Gen 15; cf. Gal 3), which in itself is a particular outworking of the divine commitment to all creatures in his presence.

7. The covenant community, secured in God's presence by divine commitment and committed to God by its own blood oath (Gen 17; Ex 24:7-11), is fundamentally priestly as indicated by the purpose of the Sinai covenant (Ex19:5-6), ${ }^{14}$ the tabernacle instructions (Ex 25-40), and those emanating from the Tent of Meeting and addressed to the individual Israelite, not the priesthood alone (Leviticus). As a particular instantiation of Adam and Eve's descendants brought into God's presence they receive instruction for life in that presence (cf. Gen 2:15-17). Like their Edenic ancestors, they fail. The topic of maintaining the cleanliness of body and soul in the divine presence continues through GK to the defiling of the temple by Manasseh (2 Kgs 21:1-18) and into the NT theology of divine presence (1 Cor 2:16; 2 Cor. 7:1).

8. Within GK's theology Moses manages the life of Israel in God's presence, ${ }^{15}$ in the desert and in the land. Thus he is instrumental in the offer (Ex 19:5) and acceptance $(24: 3,7-8)$ of the Sinai covenant instructions and their republication for the second generation (htwrh hzt, Deut 1:5; 4:44; 17:18, 19; $27: 3 ; 29: 29 ; 31: 9,24 ; 32: 46 ; k l h t w r h$ `̌r şwk mšh, Josh 1:6-9). Sanctuary life is central to the covenant community's the normal way of being. That is, covenant loyalty to God binds the people to instructions from the cultic centre which require life in the presence of God to be clean; uncleanness in the camp-land must be avoided (Num 5:3; 35:34), because the Lord walks in their midst ( $h l k$, Lev 26:12; Deut 23:12-14; cf. Gen 3:8). ${ }^{16}$ The sanctuary metaphor depicts the reality of life in God's presence and is primary; courtroom language manages disputes within that reality.

9. Recognizing the priestly voice has implications for the church's worship in solemn assembly. Ritual acts such as proclamation, confession, contrition, absolution, and penance within a well-designed liturgy officiated by trained liturgists provides regular reorientation of life in the presence of God, and

14 "The priestly task is, therefore, a dynamic one. It is to make all of Israel into 'a royalty of priests and a holy nation" (Ex 19:6)." Milgrom (1991:617) commenting on Lev 10:11.

15 Moses' leadership is a topic in Rendtorff (2005:545-559). In the NT, Jesus Christ is the new covenant mediator and the Spirit its administrator.

16 The cult is a major topic in Rendtorff (509-544). 
reaffirming the Church's essential identity as an exilic or diasporic community (Jas 1:1; 1 Pet 1:1-2).

10. The Church's essential identity as an exilic or diasporic community enables it to address humanity's essential restless wandering. This has pastoral and missionary implications. The Church's elenchtic question -"What have you done with God?" - addresses this restlessness by reorienting the diasporic membership in its daily walk. It exercises its mission task by uncovering humanity's restless wandering and by escorting all whom the Lord calls into the divine presence - the body of Christ which is the temple of the Holy Spirit - in which alone they may find rest for their souls.

11. Because Christ sent the Holy Spirit to manage the new community, covenant theology will move beyond a proper emphasis on Christ's accomplished work on the cross, to a reflection on the NT depiction of the divine presence. That is, covenant theology's Christological and soteriological reflection must be accompanied by a robust pneumatology.

\section{BIBLIOGRAPHY}

Bokedal, T 2013. “The Rule of Faith: Tracing its Origins”, JTI 7.2:233-255.

Brueggemann,W, Wolff, HW 1975. The Vitality of Old Testament Traditions. Atlanta: John Knox.

Fee, GD and Stuart, D 1993. How to Read the Bible for All its Worth. Second edition. Grand Rapids: Zondervan.

Gertz, JC, Berlejung, A, Schmid, K, Witte K 2012. T\&T Clark Handbook of the Old Testament. An Introduction to the Literature, Religion and History of the Old Testament. T\&T Clark: London.

Gorman Jr, FH 1997. Leviticus. Divine Presence and Community. ITC. Grand Rapids: Eerdmans.

Knierim, RP 1995. The Task of Old Testament Theology. Method and Cases. Grand Rapids: Eerdmans.

Leder, AC 1992. An Iconography of Order: Kingship in Exodus. A Study of the Structure of Exodus. Th D Dissertation. Toronto: Knox College, University of Toronto. 
Leder, AC 2012. Presence, then the covenants. An essay on narrative and theological precedence, Part One. NGTT, 52:179-193.

Leder, AC 2013. Presence, then the covenants. An essay on narrative and theological precedence, Part Two. NGTT, 53:207-220.

Long, VP 1999. History and Fiction: What is History? in VP Long (ed.) Israel's Past in Present Research. Essays on Ancient Israelite Historiography. Winona Lake: Eisenbrauns, 232-254.

Milgrom, J 1991. Leviticus 1-16. AB 3. New York: Doubleday.

Oosterhoff, BJ 1972. Hoe lezen wij Genesis 2 en 3? Een hermeneutische studie. Kampen: Kok.

Rendtorff, R 2005. The Canonical Hebrew Bible. A Theology of the Old Testament. Leiden: Deo.

Seitz, CR 2009. The Goodly Fellowship of the Prophets. The Achievement of Association in Canon Formation. Grand Rapids: Baker.

Von Rad, G 1984a. The Form-Critical Problem of the Hexateuch, in his The Problem of the Hexateuch and other essays. EW Trueman Dicken (trans.). London: SCM, 1-78.

Von Rad, G. 1984b. The Theological Problem of the Old Testament Doctrine of Creation, in his The Problem of the Hexateuch and other essays. EW Trueman Dicken (trans.). London: SCM, 131-143.

Von Rad, G 1984c. The Deuteronomic Theology of History in I and II Kings, in his The Problem of the Hexateuch and other essays. EW Trueman Dicken (trans.). London: SCM, 205-221.

Vos, G. 1980a The Idea of Biblical Theology as a Science and as a Theological Discipline, in Richard B.

Gaffin, Jr. (ed.) Redemptive History and Biblical Interpretation. The Shorter Writings of Geerhardus Vos. Philipsburg: Presbyterian and Reformed, 3-24.

Weinfeld, M 1981. Sabbath, Temple and Enthronement of the Lord - the Problem of the Sitz im Leben of Genesis 1:1-2:3, in Melanges bibliques et orientaux en l'honneur de M. Henri Cazelles, A Caquot and M Delcor (eds.). Neukirchen: Neukirchener, 501-512. 
Wesselius, J-W 2005. From stumbling blocks to cornerstones: The function of problematic episodes in the Primary History and in Ezra-Nehemiah, in The Interpretation of Exodus. Studies in Honour of Cornelis Houtman, R Roukema (ed.). Louvain: Peeters, 37-63.

White, H. 1973. Metahistory. The Historical Imagination in Nineteenth-Century Europe. Baltimore: Johns Hopkins.

White, H 1987. The Value of Narrativity in the Representation of Reality, in The Content of the Form. Narrative Discourse and Historical Representation. Baltimore: Johns Hopkins, 1-25.

Winter, IJ 1985. After the Battle is Over: The Stele of Vultures and the Beginning of Historical Narrative in the Art of the Ancient Near East, in Pictorial Narrative in Antiquity and the Middle Ages, vol. 16, HL Kessler and MS Simpsons (eds.). Washington: National Gallery of Art, 11-32. 
